\title{
The Trouble with Bullying in High School: Issues and Considerations in Its Conceptualization
}

\author{
Amy Bellmore ${ }^{1} \cdot$ Hsun-chih Huang ${ }^{1} \cdot$ Chelsey Bowman $^{2} \cdot$ Gerald White $^{3}$. \\ Dewey Cornell ${ }^{4}$
}

Received: 18 February 2016/Accepted: 20 July 2016/Published online: 26 July 2016

(C) Springer International Publishing 2016

\begin{abstract}
The prevalence of bullying peaks during the middle school years and declines over the high school years. This review examines the distinct features of bullying during the high school years that may explain this decline. We explore how changes in the social contexts of high-school aged adolescents influence whether bullying occurs and is reported. We focus first on changes that happen within the organizational and social aspects of high schools compared to elementary and middle schools that may influence bullying. Then we consider changes that occur through the introduction of new social contexts including work, romantic relationships, social media, and the juvenile justice system. We evaluate how these
\end{abstract}

Amy Bellmore

abellmore@wisc.edu

Hsun-chih Huang

hhuang77@wisc.edu

Chelsey Bowman

cebowman@bu.edu

Gerald White

geraldw@mun.ca

Dewey Cornell

dcornell@ virginia.edu

1 Department of Educational Psychology, University of Wisconsin-Madison, 1025 W. Johnson St., Madison, WI 53706, USA

2 Program in Counseling Psychology and Applied Human Development (CPAHD), School of Education, Boston University, Two Silber Way, Boston, MA 02215, USA

3 Faculty of Education, Memorial University of Newfoundland, St. John's, NL A1B 3X8, Canada

4 Curry School of Education, University of Virginia, Bavaro Hall 206G, PO Box 400270, Charlottesville, VA 22904, USA contexts and the perspectives of the individuals with whom teens interact in these contexts may influence how bullying-like behaviors are interpreted during the high school years. We end by providing a nudge to scholars of bullying to work more deliberately across disciplines to yield a richer understanding of bullying.

Keywords Bullying $\cdot$ High school $\cdot$ Work $\cdot$ Romantic relationships $\cdot$ Social media $\cdot$ Juvenile justice

\section{Introduction}

While there is no doubt that bullying, defined as intentional, aggressive behavior that is repeated over time and involves an imbalance in power (Olweus 1993), is a problem that school-aged adolescents face (Juvonen and Graham 2014), the bullying experiences of early- compared to middleadolescents may not be comparable. One difference is the prevalence of bullying in early versus middle adolescence. The transitional period from late childhood to early adolescence that often co-occurs with a transition into a secondary school setting such as a middle school seems to be the peak of reported bullying experiences and perpetration with declines in bullying happening across the high school years (Nansel et al. 2001; Nylund et al. 2007). This trend is consistent across nations (Smith et al. 1999) and has held up over time even when the longitudinal bullying trajectories of individual adolescents are examined (Barker et al. 2008; Sumter et al. 2012). There is also new evidence that bullying interventions are less effective with high school versus middle school students (Yeager et al. 2015). Additionally, high schoolers do not use the term bullying in accordance with researcher and adult expectations of repetition, intentionality, and power differential (Allen 2015; Hellstrom et al. 
2015). These facts together suggest that scholars should use extra caution when interpreting, labeling, and understanding bullying-type behaviors in the high school years.

In this article we explore the troubles encountered with using the term bullying to describe the behaviors and experiences of high school students. We focus on how changes in the social contexts of adolescents influence whether bullying occurs and is reported. Two types of changes are examined. First, we consider changes within a context that is consistent across development. Here we focus on schools given the changes that happen within the organizational and social aspects of secondary schools (Eccles and Roeser 2003). Second, we consider changes that occur through the introduction of the new social contexts that adolescents experience (Collins and Steinberg 2006). Among all of the new contexts that high schoolers may experience, we focus on these four: the workplace, romantic relationships, social media, and the juvenile justice system. Our rationale for these choices is that these are contexts in which social interactions that are similar to or even overlap with bullying are already known to occur. For both changing and new social contexts, the affordances that they provide for bullying or related behaviors are explored through a review of recently published empirical studies of high-school-aged youth.

\section{Changes in School Contexts in Adolescence}

The major social changes that occur when students transition from elementary to middle school have been identified (Eccles et al. 1993) and explored to some degree in relation to bullying (Smith et al. 1999). Less explored are the social changes that occur or result from changes in the transition into high school, yet these changes are similar to those experienced at the earlier transition into middle school (Eccles and Roeser 1999). In the United States, high schools often serve students for 3 or 4 years. The student population sizes of high schools are typically larger than the elementary and middle schools. Three main types of social changes that come with transition into high school seem relevant to bullying: (1) changes in relationships with adults in (i.e., teachers) and out (i.e., parents) of the school, (2) changes in peer relationships, and (3) increased participation in and autonomy in extracurricular activities.

\section{Relationships with Teachers}

The transition to high school, which includes moving into a larger school with less intensive interactions with any single teacher, brings increased distance between students and teachers that leads to decreased academic engagement (Weiss et al. 2010) and increased likelihood of dropping out (Lee and Burkam 2003). While there is little research on the costs and benefits of larger school sizes to students' relationships among their peers, one recent study found that students who attend high schools with higher teacher-student ratios report more peer victimization than students with smaller teacher-student ratios (Gottfredson and DiPietro 2011). That study also found that the number of students enrolled in the school on its own is not associated with peer victimization in high school (Gottfredson and DiPietro 2011). Thus, it appears that relationships with teachers play a key role in high school. A possible mediating mechanism for the association between high teacherstudent ratio and increased peer victimization may be a lessened sense of responsibility that teachers in such schools feel for knowing about and stopping bullying compared to teachers who work in close contact with a smaller group of students. The higher teacher-student ratio might also make it harder for teachers to adequately support students who disclose bullying events to them because such teachers may have fewer resources to do so. Resources may include training or professional staff that come with anti-bullying programs that are more likely to be present in elementary and middle school contexts. Middle school students are more likely to disclose bullying events to teachers when they have received support in the past (Boulton et al. 2013), and this pattern may extend to high school students. High school teachers may also be less likely to investigate possible bullying incidents if they feel that high school students have a greater capacity for dealing with the events on their own. All of these factors that may result from greater teacher-student distance in high schools may mean that bullying does not get identified as readily as it might in other school contexts.

\section{Relationships with Parents}

The level of parental involvement in students' school experiences declines in the high school years compared to earlier school contexts (Bhargava and Witherspoon 2015). This co-occurs with normative developmental changes in how parents and their children negotiate their relationships with one another as adolescents begin to acquire greater autonomy (Bakken and Brown 2010). Adolescents are less likely to disclose information they think is personal or that will get parental disapproval (Smetana et al. 2009). Bullying likely fits this designation as some parents blame the victim (i.e., their own child) when it occurs (Harcourt et al. 2014). Further, there is emerging evidence that high school age adolescents deliberately choose to conceal negative characteristics about their peers (Chan et al. 2015). It appears that when this decision is made about bullying it might be partially motivated by concerns about inappropriate adult actions such as not taking any action to help their child or intruding in their child's lives too much 
(DeLara 2012). Adolescents also feel that parents should already know about their plight because they have the sense that parents are omniscient (DeLara 2012).

The fact that parents do not know and that adolescents do not want to disclose about bullying is unfortunate because self-disclosure is beneficial for adolescents. Adolescents who fully disclose about their lives are less likely to be depressed and are more likely to have better relationships with their parents (Smetana et al. 2009). To better facilitate disclosure, parents need to take all disclosures about bullying seriously to ensure that adolescents feel validated and motivated to disclose about bullying in the future (Sawyer et al. 2011). It is also important that parents do not always wait to be told about experiences from their adolescents. Parents should solicit information as this is effective in promoting adolescent disclosure (Keijsers et al. 2010). Parents who take steps to become informed about their child's bullying experiences may bridge the disconnect between parenting and social relationships in high school.

\section{Relationships with Peers}

Peer relationships become increasingly important to adolescents across the high school years (Brown and Klute 2003). Changes in the ways in which peer relationships are structured and how peers relate to one another may impact the bullying experiences of youth. Chief among these changes is a decline in the perceived importance of peer perceived popularity compared to the period of early adolescence when perceived popularity is most highly valued (LaFontana and Cillessen 2010). Attention by early adolescents to the social status hierarchy in the early adolescent years may reflect the importance of social hierarchies to social group functioning, especially at times when changes to the social group membership are occurring such as the transition to middle school (Bjorklund and Pellegrini 2002). There is evidence that bullying in the early adolescent years is associated with seeking social dominance (Guerra et al. 2011; Olthof et al. 2011). After the hierarchy of the new peer group is established, bullying behaviors decrease (Pelligrini and Long 2002). This phenomenon has been most extensively studied at the transition to middle school with evidence for a downward trend in bullying behaviors continuing throughout the rest of adolescence. A potential result of this pattern is that high school students come to believe that bullying has less relevance at older ages and therefore draw different meanings (e.g., meanness rather than bullying) from the exact same behaviors.

A second major change to peer relationships that takes place across the adolescent years is the increased intimacy that occurs within friendships (Buhrmester 1990). Intimate friendships are characterized by closeness, self-disclosure, and trust. These qualities may lead to different interpretations of bullying-like behaviors that occur within such relationships. Consider teasing, which contains intentional provocation, a behavior that might overlap with bullying. Teasing also contains off-record markers, which are signals such as a smile or intonation that are used to indicate the playful nature of the interaction, and teasing is often perpetrated in the context of a close relationship such as a friendship (Keltner et al. 2001). A number of researchers have indicated that teasing is associated with bullying, to some extent (Cornell et al. 2013; Keltner et al. 1998, 2001; Kruger et al. 2006). Yet, it is hard to clearly distinguish teasing and bullying because they tend to act as an umbrella and describe a range of behaviors.

These subtle differences between bullying and teasing may be better identified by older adolescents because of increased cognitive abilities and more mature verbal skills which lead to the ability to appreciate the contradictory features of teasing (e.g., humor vs. aggression). The differences between bullying and teasing also may be better differentiated because high school students consider the context (e.g., peer group at large or close friendship) in which the interaction takes place. There is evidence that this occurs for peer ethnic discrimination; a group of racially and ethnically diverse high school students dismissed negative aspects of discriminatory messages from close friends as teasing rather than interpreting the interactions as discrimination (Douglass et al. 2015). While bullying can occur within friendships in adolescence (Wei and Jonson-Reid 2011), there may be instances that are not perceived as such by either member of the friendship dyad when teasing cues are present.

Aside from teasing, adolescents use other terms to represent social interactions that are similar to bullying that occur within high school peers relationships. In a qualitative study of U.S. high school students, Allen (2015) identified constructs that the students named as the most relevant representations of bullying-like behaviors that occurred among their peers. These included "conflict and aggression" which were perceived as distinct from one another where conflict could lead to aggression, were perceived as normative among adolescents, and mostly involved verbal and social-relational aggression. The high school students also identified "drama" as distinct from bullying, conflict, and aggression. Drama involved gossip and was seen as more typical among girls than boys. The deliberate use of specific terms that differentiate teasing, conflict, aggression, and drama from bullying, show the nuances that teens perceive in these behaviors. The fact that teens do so suggests that researchers may need to also make more nuanced interpretations of similar behaviors depending on the social contexts in which they are perpetrated. 


\section{Extracurricular Contexts}

Most high school students participate in structured extracurricular activities such as academic clubs, athletics, school newspaper, yearbook, vocational clubs, and drama or music (e.g., Mahoney et al. 2002), and scholars have argued for the significance of extracurricular settings to adolescent development (Feldman and Matjasko 2005). Pertinent to bullying, extracurricular activities are believed to provide positive social opportunities not available in the normal school day. These opportunities include more time to get to know peers who share similar interests and to build stronger social bonds that develop into supportive social networks (Feldman and Matjasko 2005).

With these potential social benefits, we might expect that extracurricular activities may buffer high school students from bullying. In fact, the little research that has been conducted on this topic suggests the effects of participation may depend on structural features of participation such as the number of activities a student is involved in and categories of activities. For example, different risk for being bullied emerged when the associations between bullying and different categories of extracurricular activities (specifically, classroom-related (such as choir), intramural sports, and interscholastic sports) were examined among $10^{\text {th }}$ grade students (Peguero 2008). High schoolers who participated in three or more classroom-related extracurricular activities were more likely to report having been bullied than students who were not involved in classroomrelated extracurricular activities. Students who participated in less than three intramural sports activities or less than three interscholastic sports activities had greater odds of being bullied than students who were not involved in intramural sports. Because so few studies have been conducted in extra-curricular settings, it is difficult to discern whether this pattern will hold across samples and school contexts. However, the fact that there were different levels of risk for being bullied as a function of the different extracurricular activity contexts underscores the need to account for extracurricular settings while attending to the different experiences that exist within various extracurricular activities.

In an extracurricular context with high levels of aggression such as a contact sport where more bullying might be expected, bullying may not occur to any higher degree than normal (see Steinfeldt et al. 2012). This may be because the benefits of team camaraderie buffer against within-team bullying. It may also be that bullying-type behaviors are occurring but that they do not include the power differential aspect of bullying because they take place in a team context. For example, Kreager (2007) reported that participation in contact sports (e.g., football and wrestling) is positively associated with fighting among males and that this association is mediated by greater peer participation in contact sports as well. Specifically, embeddedness in peer networks where all members play football substantially increases the risk for fighting but not bullying.

That the team context may change the behaviors slightly or may change how they are interpreted is also relevant for understanding hazing. Hazing is described as "any humiliating or dangerous activity expected of you to join a group, regardless of your willingness to participate" (Hoover and Pollard 2000) and is experienced by $24 \%$ of high school students who join a sports team, $16 \%$ of students who join a peer group or gang, $8 \%$ of students who join a Music, Art, or Theatre group and $7 \%$ of students who join a church group (Hoover and Pollard 2000). Key similarities between the constructs of bullying and hazing are that hazing causes harm and involves a power differential. However, more differences than similarities exist. Hazing generally coincides with the joining of a group and is believed by both team members and team leaders (e.g., coaches) to promote team cohesion (Van Raalte et al. 2007). Hazing activities can be considered consensual if victims of hazing activities are perceived to participate on a voluntary basis and the hazing activities are positive in nature (e.g., the participants are willing to risk humiliation, Tokar and Stewart 2010). Hazing participants also frequently downplay the severity of hazing activities (Hinkle Smith and Stellino 2007). These differences present a challenge to adults who seek to put an end to hazing because much of the behavior gets interpreted as promoting social bonds and relationships.

\section{Conclusions}

High school experiences provide for new types of social interactions with teachers, parents and peers that may impact whether bullying occurs or whether it is perceived as such by high school students. The evidence so far suggests that high school students are more likely to report that they experience, perpetrate, or witness behaviors such as teasing, conflict, drama, fighting, and hazing over bullying. The theoretical, methodological, and practical implications of these teen-driven distinctions should be evaluated by scholars of bullying.

\section{New Contexts that Emerge in During the High School Years}

While school is an important social context in the lives of adolescents, many other new social contexts emerge during this time (Collins and Steinberg 2006). These include new types of social institutional settings such as work, leisure, and legal environments where older individuals may face 
harsher penalties than younger individuals, and new types of relationship settings such as romantic relationships. Each of these social settings has relevance for why bullying in adolescence deserves thoughtful consideration.

\section{The Workplace}

Among the social contexts outside of school, the workplace is a highly relevant, yet understudied, context during mid and late adolescence and emerging adulthood. According to the U.S. Bureau of Labor Statistics (2014), $56 \%$ of adolescents who enrolled in school during 2014 also held a part-time job. In addition, $97 \%$ of young adults in the United States have held a job in the time between leaving high school and reaching the age of 22 (Bureau of Labor Statistics 2014). To date, the intensity of work experiences (i.e., number of hours of work) have been a main focus of research (e.g., Mortimer et al. 1996) with less emphasis on teen experiences at work that result from both individual teen characteristics and workplace characteristics (Staff and Schulenberg 2010). As a result, research on workplace bullying for adolescents lags behind the already existing extensive research literature on workplace bullying conducted with adult samples (for research with adults see Longo 2012).

A significant number (approximately $14.6 \%$ ) of adults face workplace bullying in North America and Europe every day (Keashly and Jagatic 2011; Nielsen et al. 2010). One definition of workplace bullying, adapted from Olweus's definition for school bullying (1993), describes a situation where an individual perceives him/herself as a victim of prolonged negative treatment by another individual at work (Einarsen 2000). Workplace bullying occurs within all levels of an organization including victimization of workers by their managers (referred to as downward perpetration) and by their colleagues (referred to as horizontal perpetration, Branch et al. 2013). Because of the importance of a power differential to the definition of bullying, both downward and horizontal perpetration are relevant with the downward form highlighting one key source of the power differential (i.e., the manager-worker relationship). Workplace bullying is associated with a variety of psychosocial maladjustments that are similar to those experienced by school-based victims, including mental and physical health problems and symptoms of post-traumatic stress (Nielsen and Einersen 2012).

There is no reason to expect that adolescents would be sheltered from workplace bullying compared to adults. To the contrary, because adolescent workplaces may be populated with other adolescents and not adults (Staff et al. 2009), we might expect the same peer dynamics that we see in schools and extracurricular activities. Just as the bullying-like behaviors in those contexts were not always labeled bullying by teens, there are also many work-place specific terms that are used to describe aggression in the work place. Such terms include workplace incivility (Cortina et al. 2013), workplace harassment (Einarsen et al. 2010), and workplace violence (Baron and Neuman 1996). Just as workplace bullying is relevant to adolescents, so too are many of these constructs.

Because this area is so unexplored with adolescents, there are several directions to pursue. The significance of power differentials to workplace bullying should be examined. A power differential is inherent to boss-employee relationships but not necessarily between all coworker relationships. Perceptible imbalances in power between workers are linked to feelings of job insecurity, role conflicts, and a stressful work environment, and these factors together facilitate the presence of workplace victimization (De Cuyper et al. 2009; Hauge et al. 2009; Salin 2003). It also seems important to examine whether bullyvictim roles overlap in different contexts such as school and work. Do those who experience victimization in school also experience it at work? This question could be explored both concurrently and prospectively. Smith et al. (2003) found a relationship between self-reports of victimization in the workplace and retrospective school victimization experiences such that the adults who were at highest risk for workplace victimization were bully/victims in school followed by those who were victims in school. This hints at an overlap, but prospective studies are needed.

\section{Romantic Relationships, Teen Dating Violence, and Bullying}

The emergence of romantic relationships is a major social development in the lives of adolescents (Furman and Shomaker 2008). Compared to adult romantic relationships, adolescent romantic relationships have received less attention, yet research demonstrates that romantic relationships in adolescence have an impact on adolescents' development in multiple domains (Brown et al. 1999; Furman and Shaffer 2003).

The accelerated developmental changes in physical, social and psychological realms during adolescence add an additional layer of complexity to romantic relationships. As Espelage et al. (2007) note, adolescents are "still developing their identities, social and career goals, and for the first time, their conflict management and interpersonal problem-solving skills within interactions laden with strong emotions" (p. 14.2). Puberty and shifting social dynamics, coupled with the unsuccessful management of conflict and emotion in an adolescent romantic relationship can lead to teen dating violence (TDV). The Centers for Disease Control (2015) defines TDV "as the physical, sexual, psychological, or emotional violence within a dating 
relationship, including stalking. It can occur in person or electronically and might occur between a current or former dating partner."

A number of researchers employ a developmental lens to study the link between the aggressive behavior of bullying in childhood to the abusive behavior of teen dating violence in adolescence (Pepler et al. 2006; Foshee et al. 2014). This research identifies a number of similarities between bullying and TDV involvement. Similar to bullying estimates, there is a wide range of the reported prevalence of TDV due to different sampling techniques, measurements, and definitions. Estimates of TDV range from 1.4 to $35 \%$ (Haynie et al. 2013; Hamby and Turner 2013; Howard and Wang 2003; Halpern et al. 2001). Additionally, like bully-victims, adolescents involved in TDV tend to be both aggressors and targets (O'Leary and Slep 2012). However, unlike bullying where boys report higher levels of involvement (Craig et al. 2009), adolescent girls report perpetrating TDV, with the exception of sexual dating violence, as often if not more often than adolescent boys (Foshee 1996; Halpern et al. 2001; O'Keefe 1997). More recent literature has demonstrated that adolescent females are more likely to be the victims of physical or sexual aggression compared to their male peers (Vagi et al. 2015). Furthermore, when questions about TDV ask about fear or injury, females are more likely to report TDV (Hamby and Turner 2013).

Recently, a growing body of literature has begun to examine the potential overlap between bullying involvement and involvement in teen dating violence, both with respect to perpetration and victimization. Similar to the findings on the negative psychological effects of being a target of bullying (Radliff et al. 2012; Ttofi et al. 2011), being a target of dating violence is associated with anxiety, depression, and increased substance use (Holt and Espelage 2005; Foshee et al. 2013). Pepler et al. (2006) found that adolescents who reported bullying their peers were significantly more likely to report engaging in indirect dating aggression, a form of dating aggression that avoids confrontation but involves attacks on a target's social relations, and direct forms of dating aggression such as physical harm. Similarly, Foshee et al. (2014) found an association between direct bullying perpetration and physical dating perpetration, but did not find an association between indirect forms of bullying perpetration and physical dating perpetration. This link may be explained by Connolly et al. (2000) findings that bullies engage in dating and more advanced dating activities at younger ages, perhaps when they are less able to handle conflicts and emotions.

Researchers have also found a correlation between being a target of bullying and a target of teen dating violence. Espelage et al. (2007) found that bully-victims, individuals who were both bully perpetrators and targets of bullying, were more likely to be targets of dating violence. When examining the co-occurrence of bullying and teen dating victimization, Debnam et al. (2015) reported that adolescents who were targets of bullying were also likely to be targets of TDV. The association between bullying and teen dating violence has been firmly established, but future research will need to examine the nature of the relationship between bullying and teen dating violence in order to assess whether it is causal or produced through shared risk factors as this will suggest proper directions for solutions.

\section{Involvement with Social Media}

Using social media, websites and apps where users can contribute, retrieve, and/or explore content primarily generated or shared by themselves or fellow users (McGowan et al. 2012) has become the norm for teens (Landoll 2012). Social media afford a unique context for bullying to take place (Kowalski et al. 2014). While younger adolescents and adults interact on social media as well, we consider it as a special context for adolescents because it facilitates the exploration of identity, sexuality, and intimacy which are areas in which individuals experience many changes during adolescence (Subrahmanyam and Šmahel 2011).

The prevalence of electronic bullying increases with age across the adolescent years (Smith 2015); Internet harassers are more likely to be high school aged $(64.8 \%)$ than in middle school $(27.4 \%)$ or grade school $(7.8 \%)$ (Ybarra and Mitchell 2004). We also know that high school students themselves refer to electronic bullying as particularly harmful (Hellstrom et al. 2015). However, it is unclear what the motivations of electronic bullies are during adolescence as high school students reported that the most common targets of their electronic bullying behaviors were friends (52\% of all targets), followed by another student at school $(21 \%)$, a stranger $(11 \%)$, a student in another school (9 \%) and unknown (Mishna et al. 2010). Because it is somewhat surprising that friends are the most common target, scholars should address what the intentions of the perpetrators are relative to other social motivations within the peer group.

Scholars are currently wrestling with other issues related to electronic bullying. These include which activities and venues comprise electronic bullying (Vandebosch and Van Cleemput 2009), whether defining attributes of bullying such as intent to harm, power imbalance and repetition should also be applicable to electronic bullying (Patchin and Hinduja 2015), and how electronic bullying should be addressed by schools and school-based bullying interventions (Bauman and Bellmore 2015). Similar constructs to electronic bullying that have been studied among adolescents include online harassment (e.g., Jones et al. 2015, online aggression (e.g., Law et al. 2010), aggressive forum 
posts (e.g., Moore et al. 2012), and negative online peer feedback (e.g., Koutamanis et al. 2015).

\section{The Juvenile Justice System}

All 50 U.S states have laws that are designed to protect youth from bullying. Some of these laws designate bullying as a criminal activity. An unintended consequence of these laws may be that high school-aged adolescents are at increased risk for being assigned to the juvenile justice system. This may be especially true as The U.S. Department of Education (2011) states that "most states frame legislation as law governing 'bullying' 'bullying and harassment,' or 'bullying, harassment, or intimidation' using terms interchangeably" (p. 15). This broad range of terms, together with the fact that the high school years represent the time when youth are most likely to be arrested as an offender (Sickmund and Puzzanchera 2014), may further increase the number of adolescents in the juvenile justice system. These laws will likely also promote already existing racial inequities in who gets imprisoned/involved with juvenile justice system (Vaught 2014). As we have argued earlier, the perceptions of identical behaviors change as a function of the social context in which they take place. Consequently, older adolescents and adolescents of color may encounter more legal punishment relative to other adolescents.

Legal implications make it important to identify all bullying-like behaviors in accordance with the labels that accurately capture their qualities. Beyond bullying, several behaviors have legal consequences. Harassment is one such behavior. Based on the public case of 15-yearold Phoebe Prince in a high school in Massachusetts in 2010, Stein and Mennemeier (2011) distinguished peer harassment from bullying. They indicated that peer harassment consists of three criteria: (1) it is based on race, color, national origin, sex, and disability, (2) it violates the federal civil rights the Office for Civil Rights (OCR) enforces, and (3) schools have a legal obligation to address it. Delinquency is another term frequently used to capture adolescents' disruptive behaviors that may have legal ramifications. Delinquency involves not only general physical attacking (e.g., Connolly et al. 2015; Meeus et al. 2004) and property damage (e.g., Connolly et al. 2015), but also relatively serious acts of deliberate destroying and violence (e.g., vandalism, stealing, carrying a weapon to attack someone) that are against the school order or penal law (e.g., Loeber and Farrington 2000; Office of the Attorney General 2013), and it often leads to violent crime (e.g., Meeus et al. 2004; Veliz and Shakib 2012). Research indicates that around the age of 16-17, more sensation seeking is associated with more adolescent delinquency (Harden et al. 2012). These findings support the statement that mid- and late adolescents are more likely than either children or older adults to conduct risky behaviors and violent crime (Steinberg 2013). In a similar vein, offending behavior includes adolescents' behaviors of assault, property damage and other property crime (e.g., Shulman et al. 2013). Aggression that is illegal includes physical fighting (e.g., Marsh et al. 2014; Sukhodolsky and Ruchkin 2004), weapon carrying, and hurting someone using anything as a weapon (e.g., Marsh et al. 2014). Given all of these related behaviors that may result in arrests, it appears that even though bullying may be a criminal act in some contexts, identifying bullying as something more extreme may be particularly legally detrimental for high schoolaged adolescents.

In general, behaviors perpetrated by different age groups do result in different outcomes for the perpetrators. Compared with older adolescents who may be charged (Geraghty 1997; Reddington 2002) or treated harshly by the judicial system (Steinberg 2013) for their aggravated offense and assault, children or younger adolescents who display bullying-like behaviors are less likely to receive serious punishment but intervention (e.g., Loeber et al. 2003; Stevens et al. 2000). Whether youth perpetrators are sanctioned in the criminal justice system depends on the following factors:

- Does the youth perpetrator reach the age of criminal responsibility and hold criminal intent? Ages of criminal responsibility and criminal intent with respect to illegal conduct vary across states in United States (Reddington 2002).

- How severe is the consequence of the bullying-like incident? For example, hazing causing the death of the target becomes a state jail felony (Office of the Attorney General 2013). Krug et al. (2002) reported that violence incidents in late adolescence were more likely to be fatal than violence incidents at younger ages. Similarly, middle and high school-age victims have been known to commit suicide, especially during 2009-2010 in United States (Stein and Mennemeier 2011).

- Does the bullying-like incident violate the law? For instance, if the perpetrator violates federal civil rights of the victim, he/she would be prosecuted (e.g., see Phoebe Prince's case in Stein and Mennemeier 2011).

- What are the different attitudes towards the bullyinglike incident? Is there any pressure from and any legal obligation for school, society, or victim's family to push the prosecution? (e.g., see Phoebe Prince's case in Stein and Mennemeier 2011).

These factors interactively affect the authority's decisions to treat youth perpetrators in the context of juvenile justice system. 


\section{Conclusions}

In this review, we have put forth the argument that the label given to bullying-like behaviors during the high school years is dependent on the social context in which the behaviors occur. Further, we contend that the interpretation of the behaviors is influenced by one's perspective. Teachers, parents, peers, friends, workers, romantic partners, online audiences, and the legal system have different vantage points from which they view high school-aged adolescents. The consequence of these two forces is that numerous terms that might apply to bullying behaviors in the high schools in ways that do not necessarily happen in childhood or early adolescence. The possible terms we reviewed, including harassment, incivility, abuse, discrimination, teasing, fighting, hazing, drama, violence, do not represent an exhaustive list. The extent to which scholars have explored these phenomena separately varies. Our exploration of the status of the research literature in 2016 indicates that hazing, drama, and teasing have received less research attention than harassment, abuse, and discrimination. Yet, because high-school students themselves describe these as important experiences, they should be examined. The similarities and connections between these phenomena should also be explored. This will help to alleviate the difficulty in classifying bullyinglike behaviors in the high school years that has been emphasized in this article.

The theoretical, methodological, and practical implications of this variety and the nuance needed to disentangle the phenomena present a clear opportunity for drawing from multidisciplinary perspectives. There are many disciplines already working to understand bullying or the related constructs. Outside of psychology, these include criminal justice (e.g., Hinduja and Patchin 2011), communications (Vandebosch and Van Cleemput 2009), medicine (Selkie et al. 2015) and computer science (Bellmore et al. 2015). Criminal justice approaches have clear relevance for distinguishing bullying from workplace bullying, dating aggression, harassment, delinquency, and offending behavior. Both communications and computer science can impact knowledge about the role of social media to bullying. While these different perspectives offer valuable information, they also stand to benefit from research that considers development and developmental processes. We believe that a two-way street between scholars of adolescence and those who work in other fields will provide the best conditions for both groups to overcome the troubles with identifying, eliminating, and preventing bullying in high school.

Author Contributions All authors, Amy Bellmore, Hsun-chih Huang, Chelsey Bowman, Gerald White, and Dewey Cornell, contributed to the conceptualization of the entire article. Amy Bellmore,
Hsun-chih Huang, and Chelsey Bowman wrote the article. All authors approve of the article.

\section{Compliance with Ethical Standards}

Conflict of interest The authors report no conflict of interests

\section{References}

Allen, K. P. (2015). "We don't have bullying, but we have drama": Understandings of bullying and related constructs within the social milieu of a U.S. high school. Journal of Human Behavior in the Social Environment, 25(3), 159-181. doi:10.1080/ 10911359.2014.893857.

Bakken, J. P., \& Brown, B. B. (2010). Adolescent secretive behavior: African American and Hmong adolescents' strategies and justifications for managing parents' knowledge about peers. Journal of Research on Adolescence, 20(2), 359-388. doi:10. 1111/j.1532-7795.2010.00642.x.

Barker, E. D., Arseneault, L., Brengden, M., Fontaine, N., \& Maughan, B. (2008). Joint development of bullying and victimization in adolescence: Relations to delinquency and self-harm. Journal of the American Academy of Child and Adolescent Psychiatry, 47(9), 1030-1038. doi:10.1097/CHI. 0b013e31817eec98.

Baron, R. A., \& Neuman, J. H. (1996). Workplace violence and workplace aggression: Evidence on their relative frequency and potential causes. Aggressive Behavior, 22, 161-173.

Bauman, S., \& Bellmore, A. (2015). New directions in cyberbullying research. Journal of School Violence, 14, 1-10. doi:10.1080/ 15388220.2014.968281.

Bellmore, A., Calvin, A., Xu, J., \& Zhu, X. (2015). The 5 W's of "Bullying" on Twitter: Who, What, Why, Where, When. Computers in Human Behavior, 44, 305-314. doi:10.1016/j. chb.2014.11.052.

Bhargava, S., \& Witherspoon, D. P. (2015). Parental involvement across middle and high school: Exploring contributions of individual and neighborhood characteristics. Journal of Youth and Adolescence, 44, 1702-1719. doi:10.1007/s10964-0150334-9.

Bjorklund, D. F., \& Pellegrini, A. D. (2002). The origins of human nature. Washington, DC: American Psychological Association.

Boulton, M. J., Murphy, D., Lloyd, J., Besling, S., Coote, J., Lewis, J., et al. (2013). Helping counts: Predicting children's intentions to disclose being bullied to teachers from prior social support experiences. British Educational Research Journal, 39(2), 209-221. doi:10.1080/01411926.2011.627420.

Branch, S., Ramsay, S., \& Barker, M. (2013). Workplace bullying, mobbing and general harassment: A review. International Journal of Management Reviews, 15(3), 280-299. doi:10.1111/ j.1468-2370.2012.00339.x.

Brown, B. B., Feiring, C., \& Furman, W. (1999). Missing the love boat: Why researchers have shied away from adolescent romance. In W. Furman, B. B. Brown, \& C. Feiring (Eds.), The development of romantic relationships in adolescence (pp. 1-16). New York, NY: Cambridge University Press.

Brown, B. B., \& Klute, C. (2003). Cliques, crowds, and friendships. In G. R. Adams \& M. Berzonsky (Eds.), Handbook of adolescent development (pp. 330-348). London: Blackwell.

Buhrmester, D. (1990). Intimacy of friendship, interpersonal competence, and adjustment during preadolescence and adolescence. Child Development, 61, 1101-1111. doi:10.2307/1130878.

Bureau of Labor Statistics. (2014). College enrollment and work activity of 2014 high school graduates (BLS Publication No. USDL 15-0608). Washington, DC: U.S. Department of Labor. 
Centers for Disease Control and Prevention, Injury Prevention \& Control: Division of Violence Prevention. (2015). Teen dating violence. Retrieved from http://www.cdc.gov/violencepreven tion/intimatepartnerviolence/teen_dating_violence.html.

Chan, H. Y., Brown, B. B., \& Bank, H. V. (2015). Adolescent disclosure of information about peers: The mediating role of perceptions of parents' right to know. Journal of Youth and Adolescence, 44(5), 1048-1065. doi:10.1007/s10964-015-02619.

Collins, W. A., \& Steinberg, L. (2006). Adolescent development in interpersonal context. In N. Eisenberg, W. Damon, R. M. Lerner, N. Eisenberg, W. Damon, \& R. M. Lerner (Eds.), Handbook of child psychology: Social, emotional, and personality development (6th ed., Vol. 3, pp. 1003-1067). Hoboken, NJ: Wiley.

Connolly, J., Pepler, D., Craig, W., \& Taradash, A. (2000). Dating experiences of bullies in early adolescence. Child Maltreatment, 5, 299-310.

Connolly, E. G., Schwartz, J. A., Nedelec, J. L., \& Beaver, K. M. (2015). Different slopes for different folks: Genetic influences on growth in delinquent peer association and delinquency during adolescence. Journal of Youth and Adolescence, 44, 1413-1427. doi:10.1007/s10964-015-0299-8.

Cornell, D., Gregory, A., Huang, F., \& Fan, X. (2013). Perceived prevalence of teasing and bullying predicts high school dropout rates. Journal of Educational Psychology, 105(1), 138-149. doi:10.1037/a0030416.

Cortina, L. M., Kabat-Farr, D., Leskinen, E. A., Huerta, M., \& Magley, V. J. (2013). Selective incivility as modern discrimination in organizations: Evidence and impact. Journal of Management, 39(6), 1579-1605. doi:10.1177/ 0149206311418835

Craig, W., Harel-Fisch, Y., Fogel-Grinvald, H., Dostaler, S., Hetland, J., Simons-Morton, B., et al. (2009). A cross-national profile of bullying and victimization among adolescents in 40 countries. International Journal of Public Health, 54, 216-224. doi:10. 1007/s00038-009-5413-9.

De Cuyper, N., Baillien, E., \& De Witte, H. (2009). Job insecurity, perceived employability and targets' and perpetrators' experiences of workplace bullying. Work and Stress: An International Journal of Work, Health and Organisations, 23(3), 206-224. doi:10.1080/02678370903257578.

Debnam, K. J., Waasdorp, T. E., \& Bradshaw, C. P. (2015). Examining the contemporaneous occurrence of bullying and teen dating violence victimization. School Psychology Quarterly,. doi:10.1037/spq0000124.

DeLara, E. W. (2012). Why adolescents don't disclose incidents of bullying and harassment. Journal of School Violence, 11(4), 288-305. doi:10.1080/15388220.2012.705931.

Douglass, S., Mirpuri, S., English, D., \& Yip, T. (2015). “They were just making jokes": Ethnic/racial teasing and discrimination among adolescents. Cultural Diversity and Ethnic Minority Psychology,. doi:10.1037/cdp0000041.

Eccles, J. S., Midgley, C., Wigfield, A., Buchanan, C. M., Reuman, D., Flanagan, C., et al. (1993). Development during adolescence: The impact of stage-environment fit on young adolescents' experiences in schools and in families. American Psychologist, 48(2), 90-101. doi:10.1037/0003-066X.48.2.90.

Eccles, J. S., \& Roeser, R. W. (1999). School and community influences on human development. In M. H. Bornstein \& M. E. Lamb (Eds.), Developmental psychology: An advanced textbook (4th ed., pp. 503-554). Mahwah, NJ: Lawrence Erlbaum Associates Publishers.

Eccles, J. S., \& Roeser, R. W. (2003). Schools as developmental contexts. In G. R. Adams, M. D. Berzonsky, G. R. Adams, \& M. D. Berzonsky (Eds.), Blackwell handbook of adolescence (pp. 129-148). Malden: Blackwell.
Einarsen, S. (2000). Harassment and bullying at work: A review of the Scandinavian approach. Aggression and Violent Behavior, 4, 379-401.

Einarsen, S., Hoel, H., Zapf, D., \& Cooper, C. (2010). Bullying and harassment in the workplace: Developments in theory, research, and practice (2nd ed.). Boca Raton: CRC Press.

Espelage, D. L., Holt, M. K., \& Isaia, A. (2007). Dating violence \& sexual harassment across the bully victim continuum among middle and high school students. Journal of Youth and Adolescence, 36, 799-811. doi:10.1007/s10964-006-9109-7.

Feldman, A. F., \& Matjasko, J. L. (2005). The role of school-based extracurricular activities in adolescent development: A comprehensive review and future directions. Review of Educational Research, 75, 159-210. doi:10.3102/00346543075002159.

Foshee, V. A. (1996). Gender differences in adolescent dating abuse prevalence, types and injuries. Health Education Research, 11(3), 275-286.

Foshee, V. A., McNaughton Reyes, H. L., Vivolo-Kantor, A. M., Basile, K. C., Chang, L., Faris, R., et al. (2014). Bullying as a longitudinal predictor of adolescent dating violence. Journal of Adolescent Health, 55, 439-444. doi:10.1016/j.jadohealth.2014. 03.004 .

Foshee, V. A., Reyes, H. L. M., Gottfredson, N. C., Chang, L., \& Ennett, S. T. (2013). A longitudinal examination of psychological, behavioral, academic, and relationship consequences of dating abuse victimization among a primarily rural sample of adolescents. Journal of Adolescent Health, 53, 723-729. doi:10. 1016/j.jadohealth.2013.06.016.

Furman, W., \& Shaffer, L. (2003). The role of romantic relationships in adolescent development. In P. Florsheim (Ed.), Adolescent romantic relations and sexual behaviors: Theory, research, and practical implications (pp. 3-22). Mahwah, NJ: Lawrence Erlbaum Associates Inc.

Furman, W., \& Shomaker, L. B. (2008). Patterns of interaction in adolescent romantic relationships: Distinct features and links to other close relationships. Journal of Adolescence, 31, 771-788. doi:10.1016/j.adolescence.2007.10.007.

Geraghty, T. F. (1997). Justice for children: How do we get there? The Journal of Criminal Law and Criminology, 88(1), 190-241.

Gottfredson, D. C., \& DiPietro, S. M. (2011). School size, social capital, and student victimization. Sociology of Education, 84, 69-89. doi:10.1177/0038040710392718.

Guerra, N. G., Williams, K. R., \& Sadek, S. (2011). Understanding bullying and victimization during childhood and adolescence: A mixed methods study. Child Development, 82(1), 295-310. doi:10.1111/j.1467-8624.2010.01556.x.

Halpern, C. T., Oslak, S. G., Young, M. L., Martin, S. L., \& Kupper, L. L. (2001). Partner violence among adolescents in opposite-sex romantic relationships: Findings from the National Longitudinal Study of Adolescent Health. American Journal of Public Health, 91, 1679-1685.

Hamby, S., \& Turner, H. (2013). Measuring teen dating violence in males and females: Insights from the national survey of children's exposure to violence. Psychology of Violence, 3(4), 323-339. doi:10.1037/a0029706.

Harcourt, S., Jasperse, M., \& Green, V. A. (2014). "We were sad and we were angry": A systematic review of parents' perspectives on bullying. Child and Youth Care Forum, 43(3), 373-391. doi:10. 1007/s10566-014-9243-4.

Harden, K. P., Quinn, P. D., \& Tucker-Drob, E. M. (2012). Genetically influenced change in sensation seeking drives the rise of delinquent behavior during adolescence. Developmental Science, 15(1), 150-163. doi:10.1111/j.1467-7687.2011.01115.x.

Hauge, L. J., Skogestad, A., \& Einarsen, S. (2009). Individual and situational predictors of workplace bullying: Why do 
perpetrators engage in the bullying of others? Work and Stress, 23(4), 349-358. doi:10.1080/02678370903395568.

Haynie, D. L., Farhat, T., Brooks-Russell, A., Wang, J., Barbieri, B., \& Iannotti, R. I. (2013). Dating violence perpetration and victimization among U.S. adolescents: Prevalence, patterns, and associations with health complaints and substance use. Journal of Adolescent Health, 53, 194-201. doi:10.1016/j.jadohealth. 2013.02.008.

Hellstrom, L., Persson, L., \& Hagquist, C. (2015). Understanding and defining bullying-adolescents' own views. Archives of Public Health, 73(4), 1-9.

Hinduja, S., \& Patchin, J. W. (2011). Cyberbullying: A review of the legal issues facing educators. Preventing School Failure: Alternative Education for Children and Youth, 55, 71-78.

Hinkle Smith, S. L., \& Stellino, M. B. (2007). Cognitive dissonance in athletic hazing: The roles of commitment and athletic identity. Journal of Sport and Exercise Psychology, 29, S169-S170.

Holt, M., \& Espelage, D. (2005). Social support as a moderator between dating violence victimization and well-being among African-American and Caucasian adolescents. School Psychology Review, 34, 309-328.

Hoover, N. C., \& Pollard, N. J. (2000). High school hazing initiation rites in American high schools: A national survey. Alfred, NY: Alfred University. Retrieved from http://www.alfred.edu/hs hazing/.

Howard, D. E., \& Wang, M. Q. (2003). Risk profiles of adolescent girls who were victims of dating violence. Adolescence, 38, $1-14$.

Jones, L. M., Mitchell, K. J., \& Turner, H. A. (2015). Victim reports of bystander reactions to in-person and online peer harassment: A national survey of adolescents. Journal of Youth and Adolescence, 44, 2308-2320. doi:10.1007/s10964-015-0342-9.

Juvonen, J., \& Graham, S. (2014). Bullying in schools: The power of bullies and the plight of victims. Annual Review of Psychology, 65, 159-185. doi:10.1146/annurev-psych-010213-115030.

Keashly, L., \& Jagatic, K. (2011). North American perspectives on hostile behaviors and bullying at work. In S. Einarsen, H. Hotel, D. Zapf, \& C. L. Cooper (Eds.), Bullying and harassment in the workplace: Developments in theory, research, and practice (2nd ed., pp. 41-71). Boca Raton, FL: CRC Press.

Keijsers, L., Branje, S. J. T., VanderValk, I. E., \& Meeus, W. (2010). Reciprocal effects between parental solicitation, parental control, adolescent disclosure, and adolescent delinquency. Journal of Research on Adolescence, 20(1), 88-113. doi:10.1111/j.15327795.2009.00631.x.

Keltner, D., Capps, L., Kring, A. M., Young, R. C., \& Heerey, E. A. (2001). Just teasing: A conceptual analysis and empirical review. Psychological Bulletin, 127(2), 229-248. doi:10.1037//00332909.127.2.229.

Keltner, D., Young, R. C., Heerey, E. A., Oemig, C., \& Monarch, N. D. (1998). Teasing in hierarchical and intimate relations. Journal of Personality and Social Psychology, 75(5), 1231-1247. doi:10. 1037/0022-3514.75.5.1231.

Koutamanis, M., Vossen, H. G. M., \& Valkenburg, P. M. (2015). Adolescents' comments in social media: Why do adolescents receive negative feedback and who is most at risk? Computers in Human Behavior, 53, 486-494. doi:10.1016/j.chb.2015.07.016.

Kowalski, R. M., Giumetti, G. W., Schroeder, A. N., \& Lattanner, M. R. (2014). Bullying in the digital age: A critical review and meta-analysis of cyberbullying research among youth. Psychological Bulletin, 140, 1073-1137.

Kreager, D. A. (2007). Unnecessary roughness? School sports, peer networks, and male adolescent violence. American Sociological Review, 72, 705-724. doi:10.1177/000312240707200503.
Krug, E. G., Dahlberg, L. L., Mercy, J. A., \& Ziwi, A. B. (2002). World report on violence and health Geneva. Switzerland: World Health Organization.

Kruger, J., Gordon, C. L., \& Kuban, J. (2006). Intentions in teasing: When "just kidding" just isn't good enough. Journal of Personality and Social Psychology, 90(3), 412-425. doi:10. 1037/0022-3514.90.3.412.

LaFontana, K. M., \& Cillessen, A. N. (2010). Developmental changes in the priority of perceived status in childhood and adolescence. Social Development, 19, 130-147. doi:10.1111/j.1467-9507. 2008.00522.x.

Landoll, R. R. (2012). The new frontier of peer victimization: prospective associations between adolescents' online peer victimization and internalizing symptoms (doctoral dissertation). Dissertation Abstracts International: Section B: The Sciences and Engineering, 74(2).

Law, D. M., Shapka, J. D., \& Olson, B. F. (2010). To control or not to control? Parenting behaviours and adolescent online aggression. Computers in Human Behavior, doi:10.1016/j.chb.2010.06.013.

Lee, V. E., \& Burkam, D. T. (2003). Dropping out of high school: The role of school organization and structure. American Educational Research Journal, 40, 353-393. doi:10.3102/ 00028312040002353.

Loeber, R., \& Farrington, D. P. (2000). Young children who commit crime: Epidemiology, developmental origins, risk factors, early interventions, and policy implications. Development and Psychopathology, 12, 737-762. doi:10.1017/S0954579400004107.

Loeber, R., Farrington, D. P., \& Petechuk, D. (2003). Child delinquency: Early intervention and prevention. Child Delinquency: Bulletin Series. Retrieved from https://www.ncjrs.gov/ pdffiles1/ojjdp/186162.pdf.

Longo, J. (2012). Bullying in the workplace: Reversing a culture. Silver Spring, MD: American Nurses Association/ Nursebooks.org.

Mahoney, J. L., Schweder, A. E., \& Stattin, H. (2002). Structured after-school activities as a moderator of depressed mood for adolescents with detached relations to their parents. Journal of Community Psychology, 30, 69-86.

Marsh, L., McGee, R., \& Williams, S. (2014). School climate and aggression among New Zealand high school students. New Zealand Journal of Psychology, 43(1), 28-37.

McGowan, B. S., Wasko, M., Vartabedian, B. S., Miller, R. S., Freiherr, D. D., \& Abdolrasulnia, M. (2012). Understanding the factors that influence the adoption and meaningful use of social media by physicians to share medical information. Journal of Medical Internet Research, 14, e117.

Meeus, W., Branje, S., \& Overbeek, G. J. (2004). Parents and partners in crime: A six-year longitudinal study on changes in supportive relationships and delinquency in adolescence and young adulthood. Journal of Child Psychology and Psychiatry,. doi:10.1111/ j.1469-7610.2004.00312.x.

Mishna, F., Cook, C., Gadalla, T., Daciuk, J., \& Solomon, S. (2010). Cyber bullying behaviors among middle and high school students. American Journal of Orthopsychiatry, 80(3), 362-374. doi:10.1111/j.1939-0025.2010.01040.x.

Moore, M. J., Nakano, T., Enomoto, A., \& Suda, T. (2012). Anonymity and roles associated with aggressive posts in an online forum. Computers in Human Behavior, 28(3), 861-867. doi:10.1016/j.chb.2011.12.005.

Mortimer, J. T., Finch, M. D., Ryu, S., Shanahan, M. J., \& Call, K. T. (1996). The effects of work intensity on adolescent mental health, achievement, and behavioral adjustment: New evidence from a prospective study. Child Development, 67(3), 1243-1261. doi:10.1111/j.1467-8624.1996.tb01793.x. 
Nansel, T. R., Overpeck, M., Pilla, R. S., Ruan, W. J., SimonsMorton, B., \& Scheidt, P. (2001). Bullying behaviors among US youth: Prevalence and association with psychosocial adjustment. The Journal of the American Medical Association, 285(16), 2094-2100. doi:10.1001/jama.285.16.2094.

Nielsen, M. B., \& Einersen, S. (2012). Outcomes of exposure to workplace bullying: A meta-analytic review. Work and Stress: An International Journal of Work, Health and Organisations, 26(4), 309-332. doi:10.1080/02678373.2012.734709.

Nielsen, M. B., Matthiesen, S. B., \& Einarsen, S. (2010). The impact of methodological moderators on prevalence rates of workplace bullying. A meta-analysis. Journal of Occupational and Organizational Psychology, 83(4), 955-979. doi:10.1348/ $096317909 X 481256$.

Nylund, K., Bellmore, A., Nishina, A., \& Graham, S. (2007). Subtypes, severity, and structural stability of peer victimization: What does latent class analysis say? Child Development, 78, 1706-1722. doi:10.1111/j.1467-8624.2007.01097.x.

O'Keefe, M. (1997). Predictors of dating violence among high school students. Journal of Interpersonal Violence, 12, 546-568. doi:10. 1177/088626097012004005.

O'Leary, K. D., \& Slep, A. M. S. (2012). Prevention of partner violence by focusing on behaviors of both young males and females. Prevention Science, 13, 329-339. doi:10.1007/s11121011-0237-2.

Office of the Attorney General. (2013). School crime and discipline handbook. Retrieved from https://www.texasattorneygeneral. gov/files/cj/schoolcrime_2013.pdf.

Olthof, T., Goossens, F. A., Vermande, M. M., Aleva, E. A., \& van der Meulen, M. (2011). Bullying as strategic behavior: Relations with desired and acquired dominance in the peer group. Journal of School Psychology, 49(3), 339-359. doi:10.1016/j.jsp.2011. 03.003.

Olweus, D. (1993). Bullying at school. Malden, MA: Blackwell.

Patchin, J. W., \& Hinduja, S. (2015). Measuring cyberbullying: Implications for research. Aggression and Violent Behavior, doi:10.1016/j.avb.2015.05.013.

Peguero, A. A. (2008). Bullying victimization and extracurricular activity. Journal of School Violence, 7(3), 71-85. doi:10.1080/ 15388220801955570.

Pelligrini, A. D., \& Long, J. D. (2002). A longitudinal study of bullying, dominance, and victimization during the transition from primary school through secondary school. British Journal of Developmental Psychology, 20, 259-280. doi:10.1348/ 026151002166442.

Pepler, D. J., Craig, W. M., Connolly, J. A., Yuile, A., McMaster, L., \& Jiang, D. (2006). A developmental perspective on bullying. Aggressive Behavior, 32, 376-384. doi:10.1002/ab.20136.

Radliff, K. M., Wheaton, J. E., Robinson, K., \& Morris, J. (2012). Illuminating the relationship between bullying and substance use among middle and high school youth. Addictive Behaviors, 37, 569-572. doi:10.1016/j.addbeh.2012.01.001.

Reddington, F. (2002). Age and criminal responsibility. Crime and Justice International, 18(66). Retrieved from http://www.cjima gazine.com/archives/cji9e43.html?id=25.

Salin, D. (2003). Ways of explaining workplace bullying: A review of enabling, motivating and precipitating structures and processes in the work environment. Human Relations, 56, 1213-1232. doi:10.1177/00187267035610003.

Sawyer, J. L., Mishna, F., Pepler, D., \& Wiener, J. (2011). The missing voice: Parents' perspectives of bullying. Children and Youth Services Review, 33(10), 1795-1803. doi:10.1016/j.child youth.2011.05.010.

Selkie, E. M., Fales, J. L., \& Moreno, M. A. (2015). Cyberbullying prevalence among U.S. middle and high-school aged adolescents: A systematic review and quality assessment. Journal of Adolescent Health, 58, 125-133.

Shulman, E. P., Steinberg, L. D., \& Piquero, A. R. (2013). The agecrime curve in adolescence and early adulthood is not due to age differences in economic status. Journal of Youth and Adolescence, 42, 848-860. doi:10.1007/s10964-013-9950-4.

Sickmund, M., \& Puzzanchera, C. (2014). Juvenile offenders and victims: 2014 National report. Pittsburgh, PA: National Center for Juvenile Justice.

Smetana, J. G., Villalobos, M., Rogge, R. D., \& Tasopoulos-Chan, M. (2009). Keeping secrets from parents: Daily variations among poor, urban adolescents. Journal of Adolescence, 33(2), 321-331. doi:10.1016/j.adolescence.2009.04.003.

Smith, P. K. (2015). The nature of cyberbullying and what we can do about it. Journal of Research in Special Educational Needs, 15(3), 176-184. doi:10.1111/1471-3802.12114.

Smith, P. K., Madsen, K. C., \& Moody, J. C. (1999). What causes the age decline in reports of being bullied at school? Towards a developmental analysis of risks of being bullied. Educational Research, 41, 267-285. doi:10.1080/0013188990410303.

Smith, P. K., Singer, M., Hoel, H., \& Cooper, C. L. (2003). Victimization in the school and the workplace: Are there any links? British Journal of Psychology, 94, 175-188.

Staff, J., Messersmith, E. E., \& Schulenberg, J. E. (2009). Adolescents and the world of work. In R. Lerner \& L. Steinberg (Eds.), Handbook of adolescent psychology (3rd ed., pp. 270-313). New York: John Wiley and Sons.

Staff, J., \& Schulenberg, J. E. (2010). Millennials and the world of work: Experiences in paid work during adolescence. Journal of Business and Psychology, 25, 247-255. doi:10.1007/s10869010-9167-4.

Stein, N. D., \& Mennemeier, K. A. (2011). Addressing the gendered dimensions of harassment and bullying: What domestic and sexual violence advocates need to know. Harrisburg \& Enola, PA: National Resource Center on Domestic Violence \& National Sexual Violence Resource Center.

Steinberg, L. (2013). The influence of neuroscience on US Supreme Court decisions about adolescents' criminal culpability. Nature Reviews Neuroscience, 14, 513-518. doi:10.1038/nrn3509.

Steinfeldt, J. A., Vaughan, E. L., LaFollette, J. R., \& Steinfeldt, M. C. (2012). Bullying among adolescent football players: Role of masculinity and moral atmosphere. Psychology of Men and Masculinity, 13(4), 340-353. doi:10.1037/a0026645.

Stevens, V., Oost, P. V., \& Bourdeaudhuij, I. D. (2000). The effects of an anti-bullying intervention programme on peers' attitudes and behavior. Journal of Adolescence, 23, 21-34. doi:10.1006/jado. 1999.0296.

Subrahmanyam, K., \& Šmahel, D. (2011). Digital youth: The role of media in development. New York, NY: Springer.

Sukhodolsky, D. G., \& Ruchkin, V. V. (2004). Association of normative beliefs and anger with aggression and antisocial behavior in Russian male juvenile offenders and high school students. Journal of Abnormal Child Psychology, 32(2), 225-236.

Sumter, S. R., Baumgartner, S. E., Valkenburg, P. M., \& Peter, J. (2012). Developmental trajectories of peer victimization: Offline and online experiences during adolescence. Journal of Adolescent Health, 50(6), 607-613. doi:10.1016/j.jadohealth. 2011.10.251.

Tokar, K., \& Stewart, C. (2010). Defining high school hazing: Control through clarity. Physical Educator, 67(4), 204-208.

Ttofi, M., Farrington, D., Losel, F., \& Loeber, R. (2011). Do the victims of school bullies tend to become depressed later in life? A systematic review and meta-analysis of longitudinal studies. Journal of Aggression, Conflict and Peace Research, 3(2), 63-73. doi:10.1108/17596591111132873. 
U.S. Department of Education. (2011). Analysis of state bullying laws and policies. Washington, DC: U.S. Department of Education, Office of Planning, Evaluation and Policy Development, Policy and Program Studies Service.

Vagi, K. J., Olsen, E. O., Basile, K. C., \& Vivolo-Kantor, A. M. (2015). Teen dating violence (physical and sexual) among US high school students: Findings from the 2013 national Youth Risk Behavior Survey. JAMA Pediatrics, 169(5), 474-482.

Van Raalte, J. L., Cornelius, A. E., Linder, D. E., \& Brewer, B. W. (2007). The relationship between hazing and team cohesion. Journal of Sport Behavior, 30(4), 491-507.

Vandebosch, H., \& Van Cleemput, K. (2009). Cyberbullying among youngsters: Profiles of bullies and victims. New Media and Society, 11, 1349-1371. doi:10.1177/1461444809341263.

Vaught, S. E. (2014). Structural liberalism and anti-bullying legislation. Equity and Excellence in Education, 47, 152-166. doi:10. 1080/10665684.2014.900393.

Veliz, P., \& Shakib, S. (2012). Interscholastic sports participation and school based delinquency: Does participation in sport foster a positive high school environment? Sociological Spectrum, 32, 558-580. doi:10.1080/02732173.2012.700837.
Wei, H., \& Jonson-Reid, M. (2011). Friends can hurt you: Examining the coexistence of friendship and bullying among early adolescents. School Psychology International, 32, 244-262. doi:10. 1177/0143034311402310.

Weiss, C. C., Carolan, B. V., \& Baker-Smith, E. C. (2010). Big school, small school: (Re)testing assumptions about high school size, school engagement and mathematics achievement. Journal of Youth and Adolescence, 39(2), 163-176. doi:10.1007/s10964009-9402-3.

Ybarra, M. L., \& Mitchell, K. J. (2004). Youth engaging in online harassment: Associations with caregiver-child relationships, Internet use, and personal characteristics. Journal of Adolescence, 27, 319-336. doi:10.1016/j.adolescence.2004.03.007.

Yeager, D. S., Fong, C. J., Lee, H. Y., \& Espelage, D. L. (2015). Declines in efficacy of anti-bullying programs among older adolescents: Theory and a three-level meta-analysis. Journal of Applied Developmental Psychology, 37, 36-51. doi:10.1016/j. appdev.2014.11.005. 